\title{
Rotational Eustasy as Understood in Physics
}

\author{
Nils-Axel Mörner \\ Paleogeophysics \& Geodynamics, Stockholm, Sweden \\ Email: morner@pog.nu
}

How to cite this paper: Mörner, N.-A. (2019) Rotational Eustasy as Understood in Physics. International Journal of Geosciences, 10, 709-723.

https://doi.org/10.4236/ijg.2019.106040

Received: May 26, 2019

Accepted: June 27, 2019

Published: June 30, 2019

Copyright (c) 2019 by author(s) and Scientific Research Publishing Inc. This work is licensed under the Creative Commons Attribution International License (CC BY 4.0).

http://creativecommons.org/licenses/by/4.0/

(c) (i) Open Access

\begin{abstract}
Global sea level has today become widely understood merely in terms of glacial eustasy and thermal expansion. Although this is good in theory, it is not enough to explain observational facts in nature. We know that the $17^{\text {th }}$ century was characterized by cold climate, Little Ice Age conditions, and low solar activity during the Maunder Grand Solar Minimum. In contrast, the $18^{\text {th }}$ century was characterized by warm climate conditions and a Grand Solar Maximum (with the Polar front located north of Svalbard). In terms of glacial eustasy, one would expect to find a low sea level in the $17^{\text {th }}$ century and a high sea level in the $18^{\text {th }}$ century. This is not the case in the equatorial regions, however. In the Indian Ocean and the Pacific, there was a $60-70 \mathrm{~cm}$ higher sea level in the $17^{\text {th }}$ century, and a sea level well below the present one in the $18^{\text {th }}$ century. This can only be understood in terms of "rotational eustasy". This is a novel concept, here for the first time addressed with respect to physical interpretation. It is shown that planetary beat affects Earth's rate of rotation and that this leads to oscillations of the equatorial water bulge with amplitudes of up to $\pm 70 \mathrm{~cm}$.
\end{abstract}

\section{Keywords}

Rotational Eustasy, Global Sea Level Changes, Grand Solar Maxima/Minima, Changes in Earth's Rotation, Planetary Beat on the Sun and the Earth

\section{Introduction}

The theory of sea level change includes glacial eustasy, ocean volume changes, geoidal eustasy, thermal-hyaline expansion/contraction of the water column, and changes of the rotational ellipsoid of the globe [1]-[6]. In the discussion of present and future sea level changes, the issue has generally become limited to glacial eustasy and thermal expansion [7]. Only observational facts in nature itself are good enough for a trustworthy picture, however.

Past sea level positions can be measured by watermarks, tide gauges, satellite 
altimetry, shore morphology, coastal stratigraphy, and historical and archaeological information. All of these factors have their limitations and margins of error, however (e.g. [8]).

There are more than 2000 tide gauge stations [9], but there are only a few long and continuous records. In formerly glaciated areas, the tide gauge records are dominated by glacial isostatic uplift. In other areas of the globe, the tide gauge records are usually affected by subsidence because the tide gauges are located at river-mouths where the accumulation of sediments has induced subsidence. The extraction of water from beneath cities generates sediment compaction and hence subsidence. Furthermore, many tide gauges are attached to heavy harbour constructions, which generate site-specific compaction (i.e. subsidence). Many tide gauge records are, in fact, fragmentary. Gaps in the recording may not be so serious. Gaps due to destruction (e.g. by storms and tsunamis) may generate serious discontinuities, however. This is certainly the case with relocations of the actual site of measurements. Such discontinuities invalidate straight-line trend analyses (e.g. [10]). There are also cycles to consider; the 18.6 lunar-tidal cycle and longer "lunar-tidal super cycles". Finally, there is the problem with the search for "global mean sea level change", when, in fact, eustatic sea level is a regional factor to be determined separately from region to region [11]. How can the personal selection of 6 sites [12] or 184 sites [13] provide anything but meaningless average values?

Satellite altimetry (e.g. [14]) is a new and important tool of recording sea level changes starting in late 1992. Whilst NOAA [15] gives a mean sea level rise of $+2.9 \pm 04 \mathrm{~mm} / \mathrm{yr}$, UC [16] gives a means sea level rise of $3.3 \pm 0.4 \mathrm{~mm} / \mathrm{yr}$. Both values are strongly affected by subjective "corrections" or "manipulation" [17], however. Remove these improper "calibrations" and the values change to +0.45 and $+0.65 \mathrm{~mm} / \mathrm{yr}$, respectively [18].

In this paper, I will focus on shore morphology and stratigraphy, the latitudinal differences in sea level changes during the last 500 years, the occurrence of a $+60-70 \mathrm{~cm}$ high sea level in the equatorial regions during the Little Ice Age in the $17^{\text {th }}$ century, a low sea level (peat and buildings below present sea level) in the warm period of the $18^{\text {th }}$ century, and the concept of "rotational eustasy" and its interpretation with respect to physics. The concept of "rotational eustasy" has been identified and successively built up on the basis of extensive field observations in the Indian Ocean and the Pacific [19]. In the true sense of science, it presents the logical steps from observations, via interpretations, to conclusions.

A complementary review of the observational facts is presented separately [19], and an additional a special account on biological and shore morphological criteria in [20].

\section{Material and Methods}

The concept of rotational eustasy is a direct product of the accumulation of new observational facts from a number of sites in the Indian Ocean and the Pacific. 
In this case, I refer to the following personal field works: 1) extensive and detailed investigations by an international team of specialist of a large number of islands in the Maldives in 2000-2005, 2) a study of the Sundarban delta in Bangladesh in 2010,3) a detailed and multidisciplinary study of the sea level changes during the last 500 years in Goa (India) in 2011,4) a detailed documentation of the sea level changes during the last 500 years at 10 sites in the Yasawa Islands of the Fiji Islands in 2016, and 5) a study of the sea level changes in Ouvéa Island of New Caledonia in 2018. This implies a very extensive database consisting of about 100 individual observational sites and some 80 C14-dates. Each site has been presented separately in peer reviewed scientific papers. A summary is presented below (Section 3), and an extensive review is presented in [19]. In a separate paper [20], I have addressed evidence from biological criteria (trees, corals, etc.) and shore morphology, because these data do not lie and hence seem irrefutable.

In addition to my own field documentations and sea level reconstructions, I want to refer to additional investigations of 709 atoll islands in the Pacific and Indian Ocean summarized by Duvat [21]. It refers to the changes in size and area of the individual islands over the past decade (Figure 1). It is based on independent studies by [21]-[34]. This database is interesting because it is totally objective with respect to my own. As illustrated in Figure 1 hardly any atoll has decreased in size (as would have been the case if sea level really was rising), and the vast majority have remained stable during the last decade, indicating stable sea level conditions [35].

This is consistent with a modern understanding of coastal dynamics [35] which implies that the shore (land/sea interface) can be deformed both vertically by sea level changes (besides crustal movements and compaction) and horizontally by a number of dynamic factors (Figure 2). Consequently, atoll islands my change their size laterally despite no changes in sea level.

My personal investigations in the Indian Ocean and the Pacific concerns the reconstruction of the vertical changes in sea level in Figure 2 (i.e. eustasy vs tectonics and compaction), whilst the studies summarized in Figure 1 [21] primarily concerns the horizontal (lateral) changes (i.e. the dynamic changes). The absences of a rapid rise in sea level and any tendency of a recent acceleration have also been noted by others (e.g. [36] [37]).

\section{Observational Facts}

The concept of rotational eustasy is a direct product of the accumulation of new observational facts from a number of sites in the Indian Ocean and the Pacific. In order to not include an extensive review of all the field data in this paper, I limit myself to a short review of the main findings, and present a review of the observational material separately [19].

Studies in the Maldives revealed that the $18^{\text {th }}$ century was represented by a sea level below the present level with peat below sea level, dated at 1720-1790 BP 


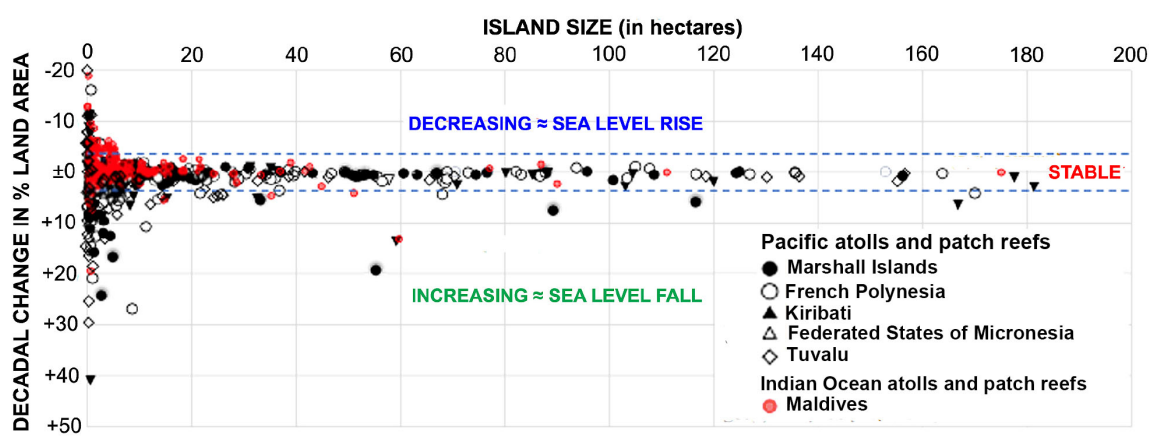

Figure 1. Changes in size of 709 atoll islandsin the Pacific and Indian Ocean (from [35], redrawn in upside-down view from [21]), providing additional evidence that the equatorial eustatic component has remaind stable for the past decades.

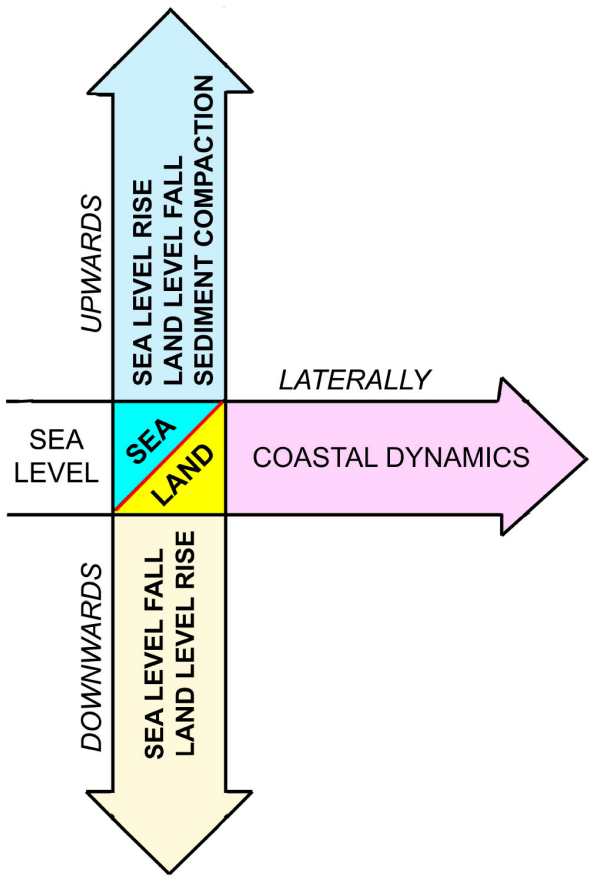

Figure 2. Coastal dynamics deform the shore laterally (horizontally), whilst the changes in sea level or land level deforms the shrelevel vertically according to Encyclopedia of Coastal Science [38].

([19] [39] [40] [41], Figs 3-6). During the $17^{\text {th }}$ century, sea level was $50-60 \mathrm{~cm}$ higher than at present. This was our first record suggesting opposed sea level changes in the Indian Ocean with respect to the general climatic changes [42].

The next place of sea level investigation was the coast of Bangladesh ([43]; [19], Fig 9). The $18^{\text {th }}$ century is represented by a distinct sea level low [39] [41] [43] with salt kilns in submarine position [44].

In Goa, India, it was possible to reconstruct the sea level change during the last 500 years with a high precision ([19] [41], Figs 5-8). The $17^{\text {th }}$ century is represented by clear morphological evidence of a $+60 \mathrm{~cm}$ higher sea level (with a C14-date giving $1615 \pm 12 \mathrm{AD}$ ). The $18^{\text {th }}$ century, on the other hand, is represented 
by a low sea level with buildings (dated 1700-1750 AD) now below sea level. The records are clear and straightforward: $\mathrm{a}+60 \mathrm{~cm}$ high in the $17^{\text {th }}$ century followed by a $-50-100 \mathrm{~cm}$ low in the $18^{\text {th }}$ century. Archaeological data and an ancient painting back up the geological data.

Consequently, the sea level changes in the equatorial Indian Ocean record a sea level story that is opposite to the general climatic history of a cold $17^{\text {th }}$ century and a warm $18^{\text {th }}$ century.

In the Fiji Islands in the Pacific, we recorded a $+70 \mathrm{~cm}$ high sea level in the $17^{\text {th }}$ century and a $-100 \mathrm{~cm}$ low sea level in the $18^{\text {th }}$ century ([19] [45] [46], Figs 10-14); i.e. a picture quite similar to the one observed in the Indian Ocean.

The latest record comes from Ouvéa Island of New Caledonia ([19] [35], Figs 15-18). There are very excellent records of a $+70 \mathrm{~cm}$ sea level in sub-recent time. This level is fresh and young (sub-recent) and recorded over the entire island. It is also seen in a sub-recent sandy shore level preceding at $+70 \mathrm{~cm}$. Figure 3 shows a former shore cliff with under-cut notches located $70 \mathrm{~cm}$ above the present high-tide level (HTL). The continuity between the present and $+70 \mathrm{~cm}$ shore marks indicates a sub-recent age of the +70 sea level. But most impressive is a rock-cut shore platform $70 \mathrm{~cm}$ above the present HTL (Figure 4). It is fresh, cut into the old reef deposits and lacking any sign of weathering, indicating a young or sub-recent age ([19], Figs 15-16). This level must correlate to the +70 $\mathrm{cm}$ sea level recorded in the Fiji Islands and dated to the $17^{\text {th }}$ century (just as was the case in the Maldives and in Goa, India).

In Figure 5, I summarize the observed sea level changes during the last 500 years as observed and documented in Bangladesh [43], Goa [41], the Maldives [39], Fiji [46], New Caledonia [35] and the present trend on a number of Pacific

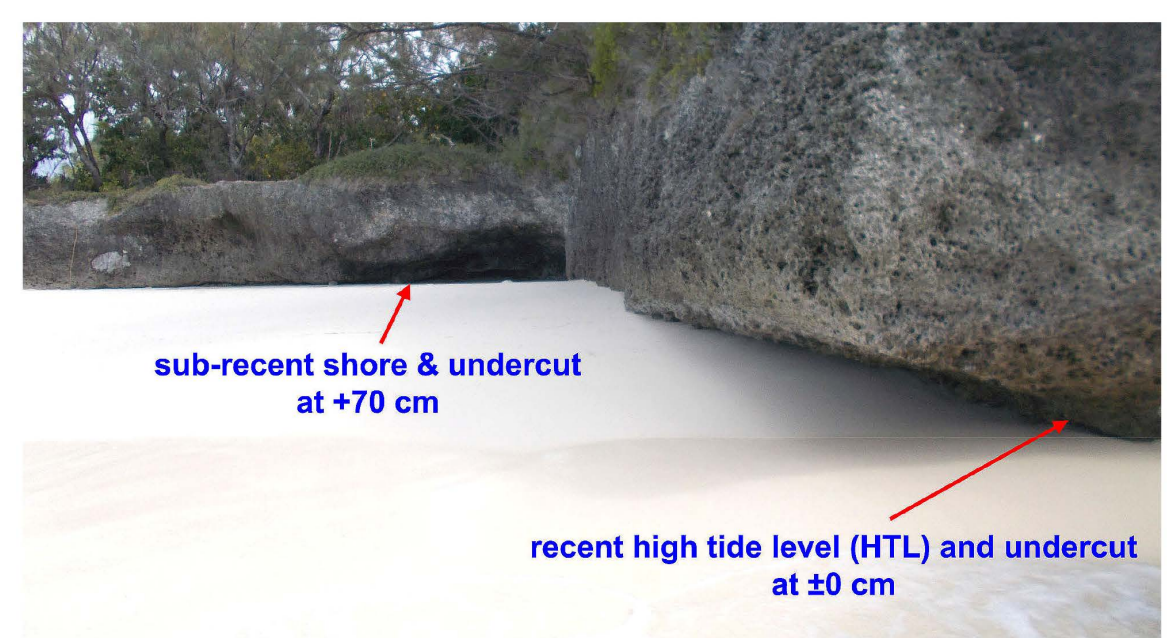

Figure 3. Double shore notches and undercut HTL shores on Ouvéa Island (photo taken at high tide). The present high tide level (HTL) is represented by extensive under-cut notches (here used as local $\pm 0.0 \mathrm{~cm}$ datum). In direct continuation of the present beach there is a dead cliff with under-cut caves representing a former HTL located $70 \mathrm{~cm}$ above the present one. The age is "sub-recent" in perfect agreement with the $+70 \mathrm{~cm}$ sea level recorded in the Fiji Islands and dated at the $17^{\text {th }}$ century [45] [46]. 


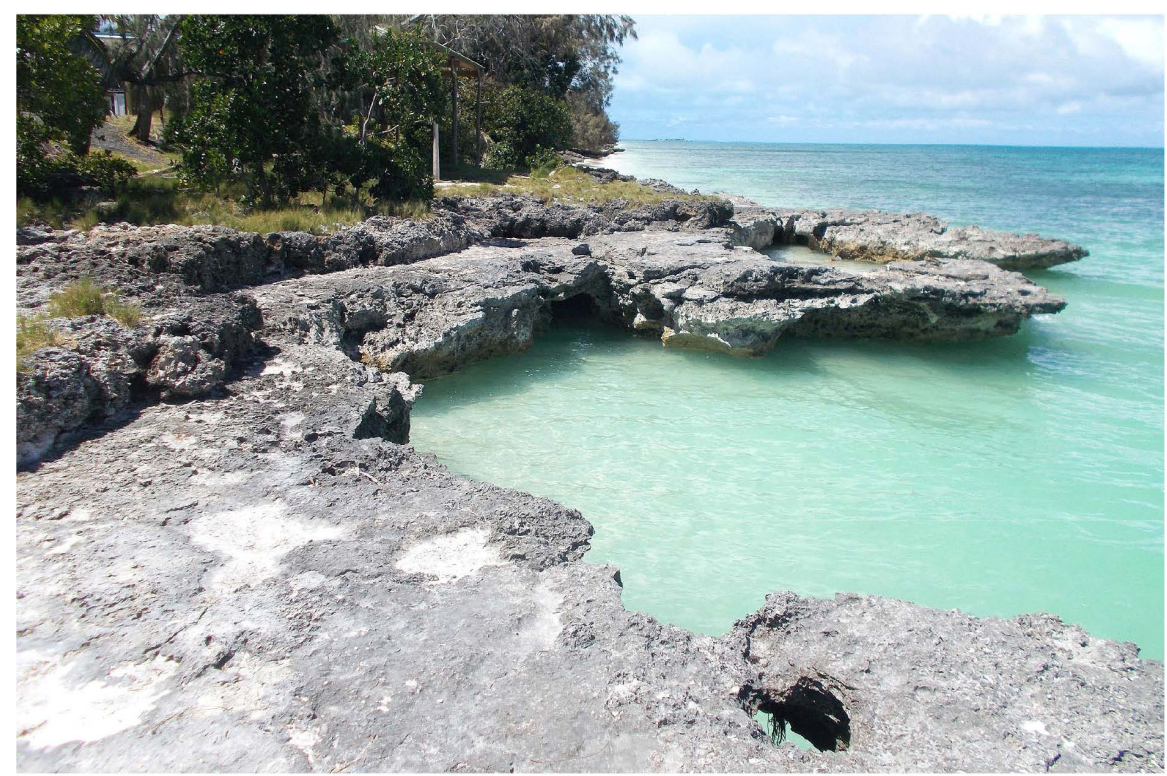

Figure 4. A very clear and distinct rock-cut platform on Ouvéa Island levelled at $+70 \mathrm{~cm}$ above the present HTL. The platform is fresh and un-weathered and cut into the older strongly weathered reef masses. The age must be sub-recent, fitting well with the $+60-70$ $\mathrm{cm}$ high sea level in the $17^{\text {th }}$ century recorded and dated in Fiji, Goa and the Maldives.

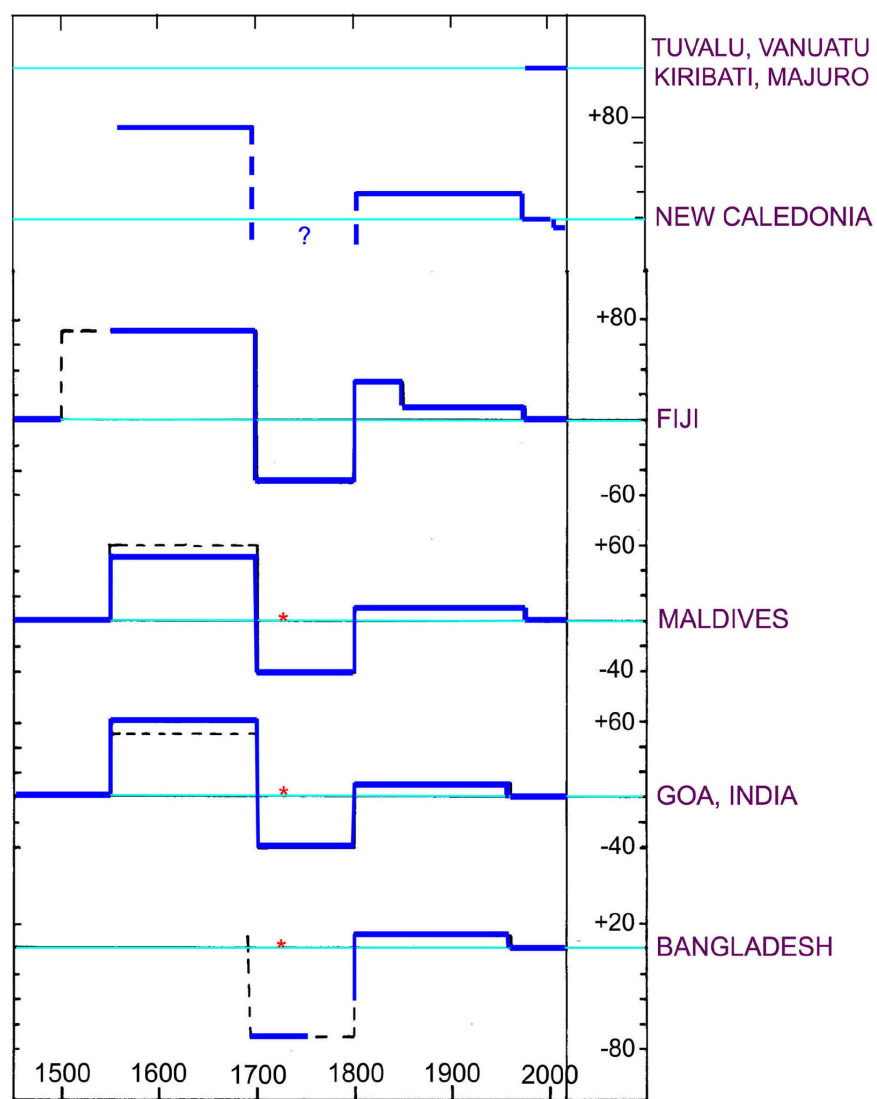

Figure 5. Sea level change documented during the last 500 years in key-sites in the Indian Ocean and the Pacific [19] [41] [48]. Red stars represent an Indian Ocean tsunami event in 1733 [49]. 
islands [47]. It shows 1) a high sea level during the $17^{\text {th }}$ century of generally cold climate, Little Ice Age conditions and the Maunder Grand Solar Minimum, 2) a low sea level during the $18^{\text {th }}$ century of generally warm climate and a Grand Solar Maximum, 3) a rise and high sea level in the early $19^{\text {th }}$ century of generally cold climate, Little Ice Age conditions and the Dalton Grand Solar Minimum, and 4) a fall in sea level in the 1960-1970 when global climate changed from cooling to the present global warming. This implies changes directly opposite from what one would expect from the glacial eustatic (and thermal expansion) point of view (cf. Figure 18 in [19]). Therefore, we must seek a new explanation.

\section{Interpretation in Terms of Physics}

The observations (Figure 5; [19]) documenting a high sea level during the cold period of the $17^{\text {th }}$ century, a low sea level during the warm period of the $18^{\text {th }}$ century, and a rise to a moderately high sea level in the early $19^{\text {th }}$ century of cold climate conditions can only be understood in terms of variations in Earth's rate of rotation; speeding-up during Grand Solar Minima and slowing-down during Grand Solar Maxima [50] [51] [52] [53].

This implies that water masses are dislocated from the north to the equatorial bulge at the speed-ups during Grand Solar Minima. Arctic water is pulled down all the way to central Portugal initiating Little Ice Age climate conditions in Europe and the North Atlantic [51]. At the same time the equatorial bulge increases (by about $60-70 \mathrm{~cm}$ in the $17^{\text {th }}$ century and by about $20-30 \mathrm{~cm}$ in the early $19^{\text {th }}$ century as shown in Figure 6).

At Grand Solar Maxima, the Gulf Stream penetrates far up into the Arctic providing warm and nice climate conditions in the whole of NW Europe [51]. The equatorial bulge, however, decreased by up to $70-100 \mathrm{~cm}$ in the 18th century, and by $10-20 \mathrm{~cm}$ at about the climate cooling in 1960-1970.

These changes in sea level are a novel finding for which I have coined the term "rotational eustasy" [5] [42] [45]. It refers to the north-south redistribution of water masses and the increase and decrease in the equatorial bulge as a function of changes in the Earth's rate of rotation (Figure 6).

If temperature continues to rise, sea level is likely to rise by about $10 \mathrm{~cm}$ up to year 2100 in the northern hemisphere and remain more or less stable in the equatorial region. If, on the other hand, we will face a new Grand Solar Minimum by about 2030-2050 [51] [52] [54], sea is likely to fall in the north and rise in the equatorial regions (Figure 6).

For the period 1850-1930, there may have been a general glacial eustatic rise in sea level as a function of the temperature rise and ice melting after the Little Ice Ages (in Figure 6). In this case, the rise would have an internal cause as proposed before [4] [55].

The geographical distribution of changes in sea level and ocean circulation (or oscillation) at the Grand Solar Minimum (the Maunder Minimum) in the $17^{\text {th }}$ century and at the Grand Solar Maximum in the $18^{\text {th }}$ century are shown in Figure 7 [5] [42] [45]. 


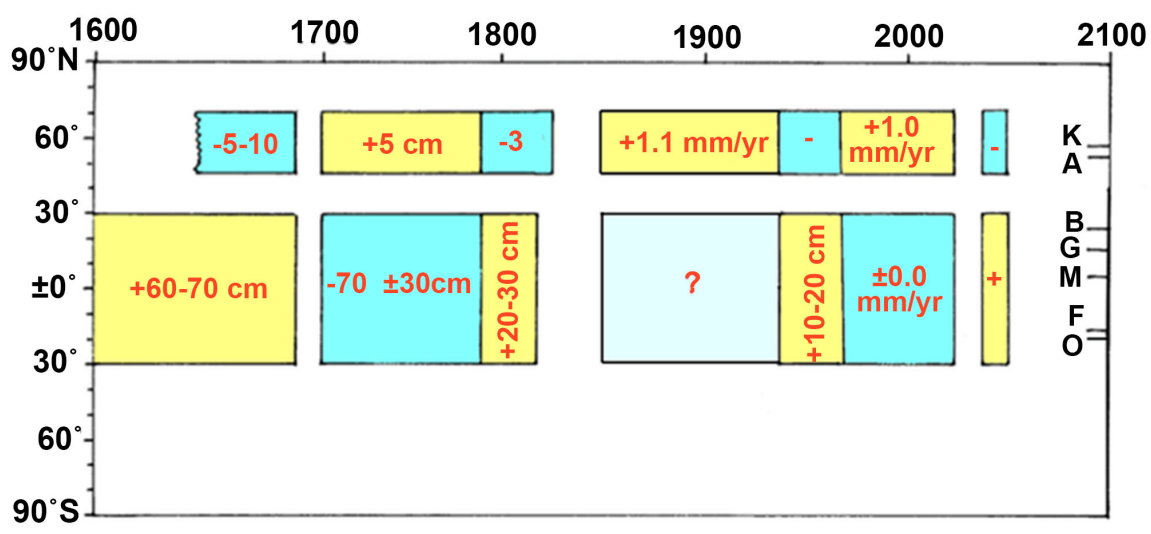

Figure 6. Latitudinal differentiation in sea level changes during the last 400 years. During the $17^{\text {th }}$ century, the Sun experienced the Maunder Grand Solar Minimum, climate was cold with Little Ice Age conditions, and the Earth's rate of rotation speeded up generating sea level fall in the north and a significant sea level rise in the equatorial region. The $18^{\text {th }}$ century, on the other hand, was a period of a Grand Solar Maximum with generally warm climate conditions and the Earth's rate of rotation slowed down generating sea level rise in the north and a significant sea level fall in the equatorial region. In the early $19^{\text {th }}$ century, the Sun experienced the Dalton Grand Solar minimum, climate was cold (a new Little Ice Age), Earth's rate of rotation speeded up and sea fell in the north and rose in the equatorial region. These changes give evidence of a predominance of rotational eustasy.

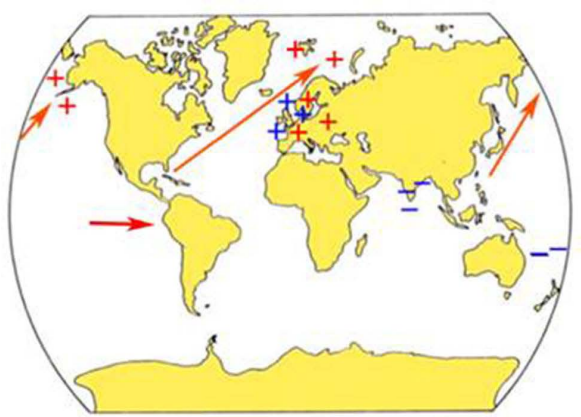

(a)

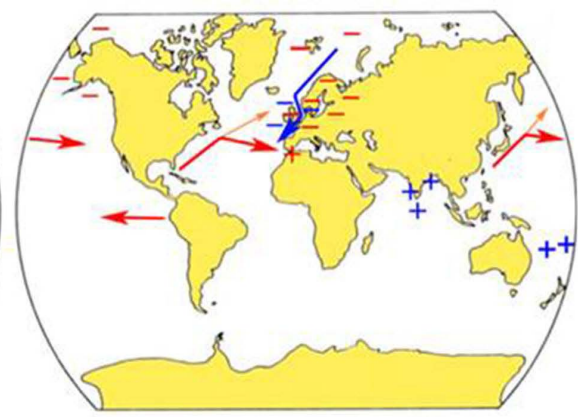

(b)

Figure 7. Sea level changes (blue \pm signs), ocean circulation (arrows), temperature changes (red \pm signs) in the equatorial Indian Ocean and Pacific, and in the Atlantic and Pacific during Grand Solar Maxima (a) with rotational slowing-down and Grand Solar Minima (b) with rotational speeding-up.

In the northern hemisphere, the changes in rotation between Grand Solar Maxima and Minima are revealed by the beat of the Gulf Stream in the North Atlantic and the Kuroshio Current in the North Pacific [51]. In the equatorial region, the same changes in rotation are seen in the rise and fall in sea level; i.e. rotational eustasy [5] [19] [42] [45]. The Pacific Decadal Oscillation (PDO) and the North Atlantic Oscillation (NAO) are parts of the Gulf Stream Beat (GSB) in the North Atlantic and the Kuroshio Current Beat (KCB) in the North Pacific [51] [53].

The expansion and contraction changes of the equatorial water bulge (Figure 4) between the $17^{\text {th }}$ and $18^{\text {th }}$ century must be a function of a speeding-up and a 
slowing-down of the Earth's rate of rotation. This is in full agreement with the observed changes in the Gulf Stream beat [51] [52]. The observed expansion/contraction changes are illustrated in Figure 8.

The changes in Earth's rate of rotation generating rotational eustatic changes in sea level are not internally but externally driven [56]. The changes in rotation were first observed in the beat of the Gulf Stream [57]. Later, it was understood that this beat (variability) ultimately had to be driven by changes in the Solar Wind [50]; i.e. solar variability. The changes in Solar Wind emission (and simultaneously also in solar irradiance emission) were found to be the function of planetary beat (the 60-yr cycle, the 84-yr Gleissberg cycle, etc.). Figure 9 gives an integrated system of the changes of planetary beat on the Sun, the Earth and the Earth-Moon system [42] [53] [58] [59].

Scafetta [60] showed that the 60 -yr cycle is a prime cycle in solar variability and that it exhibits excellent correlation with the planetary cycle of the combined effect of 5 Jupiter $(59.30 \mathrm{yr}$ ) and 2 Saturn $(58.90 \mathrm{yr}$ ) rotations around the Sun. The same applies for the Gleissberg cycle, which is the combined effect of 7 Jupiter (83.02 yr), 3 Saturn (88.35 yr) and 1 Uranus (84.3 yr) revolutions around the Sun. Neptune (164.79 yr) and Pluto (248 yr) should also be integrated in the beat systems.

The planetary cycles have a direct effect on the Sun's position with respect to the centre of mass of our planetary system [61] [62], and the internal motions of planetary-Sun barycentre [59] [63]. Obviously, the planetary beat cycles drive both the 60-yr cycle and the Grand Solar Maxima/Minima cycles (besides longer-term cycles). The impact on the terrestrial system is manifold as illustrated in Figure 9.

Of course there are other planetary cycles, both longer and shorter, that are likely to affect ocean circulation and sea level changes. The Gulf Stream exhibits 30 pulses in the last 13,000 years with cycles varying in length between 230 and 1000 years [48]. This paper, however, is about rotational eustasy during the last 500 years.

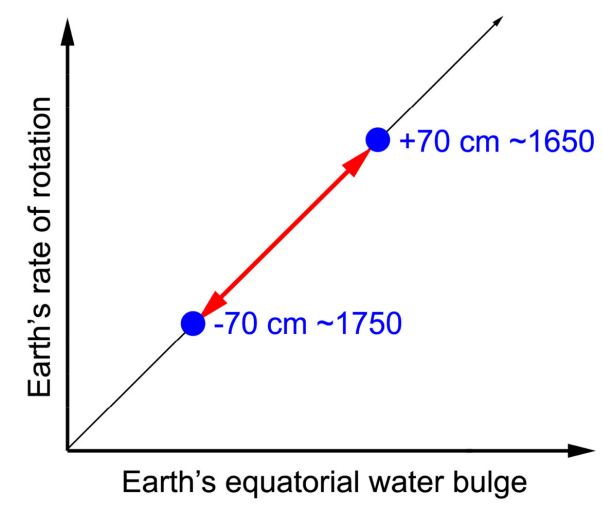

Figure 8. Observed changes in height of the equatorial water bulge between a $+70 \mathrm{~cm}$ size during the Maunder Grand Solar Minimum in the $17^{\text {th }}$ century and a $-70 \mathrm{~cm}$ size during the Grand Solar Maximum in the $18^{\text {th }}$ century. 


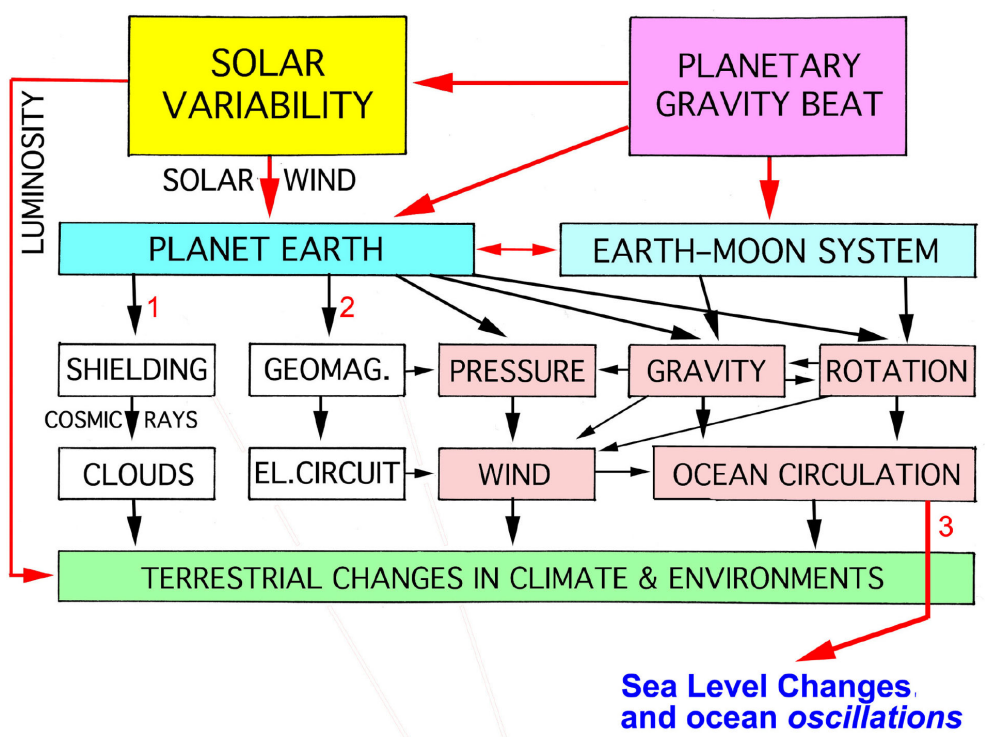

1. The Solar Wind controlls Earth's shielding and generates Grand Solar Cycles in rotational eustasy and Gulf Steam beat

2. The Solar Wind generates a main 60 -yr geomagnetic cycle like $60-y r$ cycles in rotation, climate and rotational eustasy (PDO, NAO etc)

3. The integrated effects on changes in rotational eustasy

Figure 9. Integrated terrestrial effects (including rotational eustasy) as driven by planetary beat on the Sun, the Earth and the Earth-Moon system. Brown boxes give processes that are involved in the changes in sea level and ocean "oscillations" (3). The 60-yr geomagnetic field cycle (2) provides evidence of a back-ground in changes in Solar Wind [50]. The changes in Earth's shielding (1) are a well-known characteristic of Solar Wind interaction with the Earth's geomagnetic field.

The remarkable thing with respect to rotational eustasy is that the observed changes in sea level during the last 500 years now can be traced back to an origin in the motions of the planets around the Sun and the multiple planetary beats on the Sun, the Earth and the Earth-Moon system as illustrated in Figure 9.

\section{Conclusions}

The concepts of glacial eustasy and thermal expansion/contraction cannot explain the sea level changes observed in the equatorial belt of the Indian Ocean and the Pacific. This calls for an alternative explanation.

The explanation presented is termed "rotational eustasy" [35] [42] [45]. It implies that the water masses are re-located between the high latitudes and the equatorial region in response to changes in Earth's rotation. The changes in rotation originate from the planetary beat on the Sun generating variations in emission of Solar Wind which interacts with the Earth's magnetosphere, and direct planetary beat on the Earth and the Earth-Moon system [5] [42] [45] [59] as illustrated in Figure 9.

During Grand Solar Minima, the Earth's rate of rotation speeds up and the equatorial bulge increases generating sea level rises in the Pacific and Indian Ocean. 
During Grand Solar Maxima, the Earth's rate of rotation decreases and the equatorial bulge decreases generating low sea levels in the equatorial Pacific and Indian Ocean.

The process may also be seen as a new type of "Iunar-tidal super cycles". Besides the Grand Solar Maxima/Minima cycle, we also have the 60 -yr cycle, which is a basic climatic-eustatic cycle [42] with an origin in the Jupiter-Saturn motions around the Sun [60].

The latitudinal changes in sea level during the last 400 years are summarized in Figure 6 and Figure 7. The north-south differentiation is obvious. The driving forces can only be understood in terms of rotational eustasy (Figure 8).

The concept of rotational eustasy is, of course, also valid for periods prior to the last 500 years here analysed. I leave this for future analyses, but just note that the sea level curve of the Maldives [39] [40]) includes a number of high amplitude changes in sea level. The changes are in the order of 0.6 to $1.2 \mathrm{~m}$ and they are likely to be the function of changes in rotational eustasy (because of their amplitude, rates and anti-correlation with climatic-eustatic records from northern latitudes).

The concept is, of course, also valid for the future. Therefore, it is to be expected that sea level will rise in the equatorial regions during the next Grand Solar Minimum likely to occur at about 2030-2050 [54].

\section{Acknowledgements}

When I in 1999 was elected president of the INQUA Commission on Sea Level Changes and Coastal Evolution, I initiated an international research project on sea level changes in the Maldives. We were soon able to document a number of surprises; a $10-20 \mathrm{~cm}$ fall in sea level at around 1970, submarine peat from the $18^{\text {th }}$ century and a $+60 \mathrm{~cm}$ high sea level from the $17^{\text {th }}$ century. This was the beginning of our understanding that glacial eustasy and thermal expansion were concepts not able to explain our observations. After additional documentation in Bangladesh, Goa, Fiji and New Caledonia, it is now time for this presentation of the concept of rotational eustasy. I declare no conflict of interest. I thank all colleagues involved and all local persons so generously assisting us in the field. I am indebted to Pamela Matlack-Klein for skilful linguistic review of both this paper.

\section{Conflicts of Interest}

The author declares no conflicts of interest regarding the publication of this paper.

\section{References}

[1] Fairbridge, R.W. (1961) Eustatic Changes in Sea Level. Physics Chemistry of the Earth, 4, 99-185. https://doi.org/10.1016/0079-1946(61)90004-0

[2] Mörner, N.-A. (1976) Eustasy and Geoid Changes. Journal of Geology, 84, 123-151. https://doi.org/10.1086/628184 
[3] Mörner, N.-A. (1987) Models of Global Sea Level Changes. In: Tooley, M.J. and Shennan, I., Eds., Sea Level Changes, Blackwell, Oxford, 333-335.

[4] Mörner, N.-A. (2013) Sea Level Changes: Past Records and Future Expectations. Earth \& Environment, 24, 509-536. https://doi.org/10.1260/0958-305X.24.3-4.509

[5] Mörner, N.-A. (2018) Development of Ideas and New Trends in Modern Sea Level Research: The Pre-Quaternary, Quaternary, Present and Future. In: Ramkumar, M., et al., Eds., Coastal Zone Management. Global Perspectives, Regional Processes, Local Issues, Elsevier, Amsterdam, Chapter 2, 13-62. https://doi.org/10.1016/B978-0-12-814350-6.00002-1

[6] Khan, A.A. (2018) Why Would Sea-Level Rise for Global Warming and Polar Ice Melt? Geoscience Frontiers, 10, 481-494. https://doi.org/10.1016/j.gsf.2018.01.008

[7] IPCC (Intergovernmental Panel on Climate Change) (2013) Fifth Assessment Report: Climate Change. Cambridge University Press, Cambridge, 1535 p. https://doi.org/10.1017/CBO9781107415324

[8] Mörner, N.-A. (2004) Estimating Future Sea Level Changes. Global Planetary Change, 40, 49-54. https://doi.org/10.1016/S0921-8181(03)00097-3

[9] The PSMSL Database (2018). http://www.psmsl.org/data/obtaining

[10] Mörner, N.-A. and Matlack-Klein, P. (2017) The Fiji Ride-Gauge Stations. International Journal of Geosciences, 8, 536-544. https://doi.org/10.4236/ijg.2017.84028

[11] Mörner, N.-A. (1986) The Concept of Eustasy. A Redefinition. Journal of Coastal Research, No. 1, 49-51.

[12] Holgate, S.J. (2007) On the Decadal Rates of Sea Level Change during the Twentieth Century. Geophysical Research Letters, 34, L01602. https://doi.org/10.1029/2006GL028492

[13] UC (University of Colorado) (2013) Sea Level Research Group of University of Colorado. http://sealevel.colorado.edu

[14] AVISO (2019) Why Satellite Altimetry-Aviso. https://www.aviso.altimetry.fr/en/techniques/altimetry.html

[15] NOAA (2014) Laboratory for Satellite Altimetry/Sea Level Rise. http://www.star.nesdis.noaa.gov/sod/lsa/SeaLevelRise

[16] UC (University of Colorado) (2015) Sea Level Research Group of University of Colorado. http://sealevel.colorado.edu

[17] Mörner, N.-A. (2017) Sea Level Manipulation. International Journal of Engineering Science Invention, 6, 48-51. http://www.ijesi.org/papers/Vol(6)8/Version-1/G0608014851.pdf

[18] Mörner, N.-A. (2015) Glacial Isostasy: Regional-Not Global. International Journal of Geosciences, 6, 577-592. https://doi.org/10.4236/ijg.2015.66045

[19] Mörner, N.-A. (2019) Rotational Eustasy as Observed in Nature. International Journal of Geosciences, in Press.

[20] Mörner, N.-A. (2019) Biology and Shore Morphology: Keys to Proper Reconstruction of Sea Level Changes. Journal of Marine Biology and Aquascape, 1, 1-5.

[21] Duvat, V.K.E. (2019) A Global Assessment of Atoll Island Planform Changes over the Past Decades. WIREs Climate Change, 10, e557.

https://doi.org/10.1002/wcc.557

[22] Webb, A.P. and Kench, P.S. (2010) The Dynamic Response of Reef Islands to Sea-Level Rise: Evidence from Multi-Decadal Analysis of Island Change in the Central Pacific. Global and Planetary Change, 72, 234-246. 
https://doi.org/10.1016/j.gloplacha.2010.05.003

[23] Rankey, E.C. (2011) Nature and Stability of Atoll Island Shorelines: Gilbert Island Chain, Kiribaati, Equatorial Pacific. Sedimentology, 58, 1831-1859.

https://doi.org/10.1111/j.1365-3091.2011.01241.x

[24] Dunne, R.P., Barbosa, S.M. and Woodworth, P.L. (2012) Contemporary Sea Level in the Chagos Archipelago, Central Indian Ocean. Global and Planetary Change, 82-83, 25-37. https://doi.org/10.1016/j.gloplacha.2011.11.009

[25] Ford, M. (2012) Shoreline Changes on an Urban Atoll in the Central Pacific Ocean: Majuro Atoll, Marshall Islands. Journal of Coastal Research, 28, 11-22. https://doi.org/10.2112/JCOASTRES-D-11-00008.1

[26] Ford, M. (2013) Shoreline Changes Interpreted from Multi-Temporal Aerial Photographs and High Resolution Satellite Images: Wotje Atoll, Marshall Islands. Remote Sensing of Environment, 135, 130-140. https://doi.org/10.1016/j.rse.2013.03.027

[27] Biribo, N. and Woodroffe, C.D. (2013) Historical Area and Shoreline Change of Reef Islands around Tarawa Atoll, Kiribati. Sustainability Science, 8, 345-362. https://doi.org/10.1007/s11625-013-0210-Z

[28] Kench, P.S., Thompson, D., Ford, M.R., Ogawa, H. and McLean, R.F. (2015) Coral Islands Defy Sea-Level Rise over the Past Century: Records from a Central Pacific Atoll. Geology, 43, 515-518. https://doi.org/10.1130/G36555.1

[29] Ford, M.R. and Kench, P.S. (2015) Multi-Decadal Shoreline Changes in Response to Sea Level Rise in the Marshall Islands. Anthropocene, 11, 14-24. https://doi.org/10.1016/j.ancene.2015.11.002

[30] Ford, M.R. and Kench, P.S. (2016) Spatiotemporal Variability of Typhoon Impacts and Relaxation Intervals on Jaluit Atoll, Marshall Islands. Geology, 44, 159-162. https://doi.org/10.1130/G37402.1

[31] Testut, L., Duvat, V., Ballu, V., Fernandes, R.M.S., Pouget, F., Salmon, C. and Dyment, J. (2016) Shoreline Changes in a Rising Sea Level Context: The Example of Grande Glorieuse, Scattered Islands, Western Indian Ocean. Acta Oecologica, 72, 110-119. https://doi.org/10.1016/j.actao.2015.10.002

[32] Purkis, S.J., Gardiner, R., Johnston, M.W. and Sheppard, C.R.C. (2016) A HalfCentury of Coastline Change in Diego Garcia-The Largest Atoll Island in the Chagos. Geomorphology, 261, 282-298. https://doi.org/10.1016/j.geomorph.2016.03.010

[33] Duvat, V.K.E. and Pillet, V. (2017) Shoreline Changes in Reef Islands of the Central Pacific: Takapoto Atoll, Norther Tuamotu, French Polynesia. Geomorphology, 282, 96-118. https://doi.org/10.1016/j.geomorph.2017.01.002

[34] Duvat, V.K.E., Salvar, B. and Salmon, C. (2017) Drivers of Shoreline Change in Atoll Reef Islands of the Tuamotu Archipelago, French Polynesia. Global and Planetary Change, 158, 134-154. https://doi.org/10.1016/j.gloplacha.2017.09.016

[35] Mörner, N.-A. (2018) Absolute Evidence of the Absence of an On-Going Sea Level Rise on Ouvéa of New Caledonia. SSRG International Journal of Geoinformatics and Geological Science, 5, 30-33.

https://doi.org/10.14445/23939206/IJGGS-V5I3P104

http://www.internationaljournalssrg.org/IJGGS/2018/Volume5-Issue3/IJGGS-V5I3 P104.pdf

[36] Park, A. and Ollier, C. (2015) Sea Level Rise for India since the Start of Tide Gauge Records. Arabian Journal of Geosciences, 8, 6483-6495.

https://doi.org/10.1007/s12517-014-1739-6 
[37] Park, A. and Ollier, C. (2019) Pacific Sea Levels Rising Very Slowly and Not Accelerating. Questiones Geographicae, 38, 179-184. https://doi.org/10.2478/quageo-2019-0007

[38] Mörner, N.-A. (2017) Coastal Dynamics. In: Finkl, C.W. and Makowski, C., Eds., Encyclopedia of Coastal Science, Springer, Cham. https://doi.org/10.1007/978-3-319-48657-4_374-1

[39] Mörner, N.-A. (2007) Sea Level Changes and Tsunamis, Environmental Stress and Migration Overseas. The Case of the Maldives and Sri Lanka. Internationales Asienforum, 38, 353-374.

http://scienceandpublicpolicy.org/wp-content/uploads/2010/01/Case_of_the_Maldi ves_and_Sri_Lanka.pdf

[40] Mörner, N.-A. (2011) The Maldives as a Measure of Sea Level and Sea Level Ethics. In: Easterbrook, D.J., Ed., Evidence-Based Climate Science, Elsevier, Amsterdam, Chapter 7, 197-209. https://doi.org/10.1016/B978-0-12-385956-3.10007-5

[41] Mörner, N.-A. (2017) Coastal Morphology and Sea-Level Changes in Goa, India, during the Last 500 Years. Journal of Coastal Research, 33, 421-434.

https://doi.org/10.2112/JCOASTRES-D-16A-00015.1

[42] Mörner, N.-A. (2015) Multiple Planetary Influence on the Earth. In: Mörner, N.-A., Ed., Planetary Influence on the Sun and the Earth, and a Modern Book-Burning, Nova Science Publishers, |Hauppauge, Chapter 4, 39-50.

[43] Mörner, N.-A. (2010) Sea Level Changes in Bangladesh: New Observational Facts. Energy and Environment, 21, 249-263. https://doi.org/10.1260/0958-305X.21.3.235

[44] Hanebuth, T.J.J., Kudrass, H.R., Linstädter, J., Islam, B. and Zander, A.M. (2013) Rapid Coastal Subsidence in the Central Ganges-Brahmaputra Delta (Bangladesh) since the 17th Century Deduced from Submerged Salt-Producing Kilns. Geology, 41, 987-990. https://doi.org/10.1130/G34646.1

[45] Mörner, N.-A. (2017) Our Oceans-Our Future: New Evidence-Basted Sea Level Records from the Fiji Islands for the Last 500 Years Indicating Rotational Eustasy and Absence of a Present Rise in Sea Level. International Journal of Earth and Environmental Sciences, 2, 137. https://doi.org/10.15344/2456-351X/2017/137

[46] Mörner, N.-A. and Matlack-Klein, P. (2017) New Records of Sea Level Changes in the Fiji Islands. Oceanography and Fishery, Open Access Journal, 5, 20. https://doi.org/10.19080/OFOAJ.2017.05.555666

[47] Mörner, N.-A. (2016) Sea Level Changes as Observed in Nature. In: Easterbrook, D.J., Ed., Evidence-Based Climate Science, Elsevier, Amsterdam, 2nd Edition, Chapter 12, 215-229. https://doi.org/10.1016/B978-0-12-804588-6.00012-4

[48] Mörner, N.-A. (2016) Ocean Circulation Changes. In: Mörner, N.-A., Ed., New Dawn of Truth, Climate Change: Science and Geoethics, London Conference Volume, 92-96. https://www.researchgate.net/publication/306013278

[49] Mörner, N.-A., Laborel, J. and Dawson, S. (2008) Submarine "Sandstorms" and Tsunami Events in the Indian Ocean. Journal of Coastal Research, 24, 1608-1611. https://doi.org/10.2112/07-0977.1

[50] Mörner, N.-A. (1996) Global Change and Interaction of Earth Rotation, Ocean Circulation and Paleoclimate. The Anais da Academia Brasileira de Ciências, 68, 77-94.

https://www.researchgate.net/profile/Nils-Axel_Moerner/publication/283971240_G lobal_Change_and_interaction_of_Earth_rotation_ocean_circulation_and_paleocli mate/links/5ba8e77fa6fdccd3cb6f6e6e/Global-Change-and-interaction-of-Earth-rot ation-ocean-circulation-and-paleoclimate.pdf?origin=publication_detail 
[51] Mörner, N.-A. (2010) Solar Minima, Earth's Rotation and Little Ice Ages in the Past and in the Future: The North Atlantic-European Case. Global and Planetary Change, 72, 282-293. https://doi.org/10.1016/j.gloplacha.2010.01.004

[52] Mörner, N.-A. (2011) Arctic Environment by the Middle of This Century. Earth and Environment, 22, 207-218. https://doi.org/10.1260/0958-305X.22.3.207

[53] Mörner, N.-A. (2013) Solar Wind, Earth's Rotation and Changes in Terrestrial Climate. Physical Review and Research International, 3, 117-136.

[54] Mörner, N.-A. (2015) The Approaching New Grand Solar Minimum and Little Ice Age Climate Conditions. Natural Science, 7, 510-518. https://doi.org/10.4236/ns.2015.711052

[55] Mörner, N.-A. (1992) Sea Level Changes and Earth's Rate of Rotation. Journal of Coastal Research, 8, 966-971. https://www.jstor.org/stable/4298049

[56] Scafetta, N. (2018) Towards a Better Understanding of Natural Climate Variability. In: Mörner, N.-A., Matlack-Klein, P. and Araujo, M.A., Eds., Basic Science: How processes in the Sun, Atmosphere and Ocean Affect Weather and Climate, The Porto Climate Conference 2018, The Conference Volume of Extended Abstracts, 59-60. https://www.researchgate.net/publication/326882331 https://www.portoconference2018.org/videos.html

[57] Mörner, N.-A. (1984) Planetary, Solar, Atmospheric, Hydrospheric and Endogene Processes as Origin of Climatic Changes of the Earth. In: Mörner, N.-A. and Karlén, W., Eds., Climatic Changes on a Yearly to Millennial Basis, Reidel Publ. Co., Dordrecht, 483-507. https://doi.org/10.1007/978-94-015-7692-5_48

[58] Mörner, N.-A. (2012) Planetary Beat, Solar Wind and Terrestrial Climate. In: Escaropa, C.D. and Berós Cruz, A.F., Eds., Solar Wind: Emission, Technology and Impacts, Nova Science Publishers, New York, Chapter 2, 47-66.

[59] Mörner, N.-A. (2013) Planetary Beat and Solar-Terrestrial Responses. Pattern Recognition in Physics, 1, 107-116. https://doi.org/10.5194/prp-1-107-2013

[60] Scafetta, N. (2012) A Shared Frequency Set between the Historical Mid-Latitude Aurora Records and the Global Surface Temperature. Journal of Atmospheric and Solar-Terrestrial Physics, 74, 145-163. https://doi.org/10.1016/j.jastp.2011.10.013

[61] Landscheidt, T.J. (1981) Swinging Sun, 79-Year Cycle, and Climate Change. Journal of Interdisciplinary Cycle Research, 12, 3-19.

http://bourabai.kz/landscheidt/swinging.htm https://doi.org/10.1080/09291018109359720

[62] Chervátová, I. (1988) The Solar Motion and the Variability of Solar Activity. Advances in Space Research, 8, 147-150. https://doi.org/10.1016/0273-1177(88)90184-6

[63] Mörner, N.-A. (2015) Concluding Remarks. In: Mörner, N.-A., Ed., Planetary Influence on the Sun and the Earth, and a Modern Book-Burning, Nova Science Publishers, Hauppauge, Chapter 9, 109-121. 